\title{
From the Hood to the White House: The Cultural Imaginary of Presidential Blackness in Head of State
}

\section{Atalie Gerhard, M.A.}

Saarland University

\begin{abstract}
This article analyzes the film Head of State's cultural imaginary of presidential blackness that signifies national progress while sublimating social conflict. The plot imagines a black man from the hood successfully running for presidency, living the American dream, and becoming an unconventional national icon. His symbolic blackness comprises two markers of difference: his identification with the disenfranchised hood and the black diaspora. As he challenges racial inequality in the U.S. as well as moral corruption among the élite, he unifies one historical fiction of America. I focus on how the film attributes an anti-establishment legacy to a minority president based on his countercultural identity performances although he remains complicit with foundational institutions of government. While the film projects hopes for future racial and economic equality upon a fictional black president and strategically redefines the American dream, I argue that it appropriates and revives American exceptionalist myths.
\end{abstract}

Keywords: race, the presidency, blackness, Head of State (movie), American exceptionalism

Every presidential election in the U.S. is surrounded by debates concerning the specific values that candidates must represent in the eyes of the public while comparisons to past presidents who shaped the nation's past abound. This pattern is represented in the film Head of State (2003; dir. Chris Rock) about a fictional first black president who particularly speaks to his urban hood and the black diaspora in a comically exaggerated manner. As such, 
the film faces the task of addressing the issues that divide real-life inhabitants of the U.S. at a specific moment in time such as racial and social inequality and the corruption of the political and economic élite while still fashioning in a believable way a unified community of citizens inhabiting what Jeff Smith calls "the ongoing 'fiction' that is America" in his study The Presidents We Imagine: Two Centuries of White House Fictions on the Page, on the Stage, Onscreen, and Online (2009). ${ }^{1}$ The film Head of State prominently explores the possibility of a black man from the hood successfully running for the office of President of the United States of America and thus living his dream. ${ }^{2}$ By virtue of his origins, the protagonist Mays Gilliam is seen to present a contrast to past white middle-class presidents, but because he is different, he can found a new style of presidency like the idolized Founding Fathers did in their eras and his image is finally imagined alongside theirs at Mount Rushmore. His symbolical blackness can thereby be extended to comprise two markers of his identity that distinguish him from the white middle class élite: his urban hood descent and his sense of belonging to a transatlantic black diaspora. Derived from the Jewish Exodus narrative, the concept of a diaspora united by shared traditions and a history of transcultural enslavement is critically referenced with regard to black communities by Paul Gilroy in his book, The Black Atlantic: Modernity and Double Consciousness (1993). ${ }^{3}$ He outlines how late $19^{\text {th }}$ and $20^{\text {th }}$ century Afrocentric movements invoked mythical origins in Egypt or Ethiopia to forge a sense of community among black populations worldwide and advocate for racial pride while invoking cultural nationalism. ${ }^{4}$ For the purposes of this article, I follow Gilroy's approach to studying the identity politics of Western performances of blackness that claim diasporic relevance with attention to their discursive constructions.

The film Head of State imagines the African American alderman Mays Gilliam nominated as his country's first black presidential candidate after he rescues an elderly woman from her burning house and thereby conjures stereotypes of both marginality and originality which are associated with

1 Jeff Smith, The Presidents We Imagine: Two Centuries of White House Fictions on the Page, on the Stage, Onscreen, and Online (Madison: Wisconsin University Press, 2009), 9.

2 Head of State, directed by Chris Rock (Universal City: DreamWorks, 2003), DVD.

3 Paul Gilroy, The Black Atlantic: Modernity and Double Consciousness (Cambridge: Harvard University Press, 1993), 205.

4 Gilroy, 20; 207. 
blackness in the $21^{\text {st }}$ century U.S. As he himself claims to represent the polar opposite of the U.S. élite within the story, Mays Gilliam's campaign explores the capacity of establishment politics to integrate a stereotyped "other" of broad public appeal. Thus, as a fictional narrative about a president that represents his run for office as a battle over norms and values which he must diplomatically navigate, ${ }^{5}$ the film Head of State depicts the duty that Michael Novak also attributes to any presidential candidate to shape citizens' perceptions of the everyday living conditions they experience in the U.S. ${ }^{6}$ Even before he is nominated by his party, Mays Gilliam's actions are both reflective of the existing power asymmetries and prescriptive of how to criticize them from the specific point of view that I term his blackness in the context of this film. In this sense, I aim to show how the origins of Mays Gilliam's symbolically meaningful blackness can appear as both a mirror of social conflict and the driving force behind his political efforts for national progress.

In this context, Mays Gilliam's presidential blackness paradoxically allows him to simultaneously embody the struggles of the electoral mainstream of the American citizenry in an age of racial discrimination, political disenchantment, and class divisions as well as the wish of the disenfranchised communities he pertains to, to overcome these conditions and realize Martin Luther King Jr.'s enduring American dream of racial equality. Coined by the historian James Truslow Adams in 1931, the term "American dream" dominantly signifies equal opportunities for every U.S. citizen to attain a high standard of living by realizing their full potential in the absence of any social restrictions. ${ }^{8}$ Since this definition, the ideal has been appropriated by the U.S. political right and left alike but remained unchallenged despite its elusiveness. ${ }^{9}$ Still, the myth of the American dream is perpetuated by individual tokens from disenfranchised communities such as self-made celebrities of color to the effect that social hierarchies may

5 Smith, 11.

6 Michael Novak, Choosing Our King: Powerful Symbols in Presidential Politics (New York: Macmillan, 1974), 8.

7 Martin Luther King Jr. (1965), "Our God is Marching On," in The Eyes on the Prize. Civil Rights Reader: Documents, Speeches, and Firsthand Accounts from the Black Freedom Struggle, 1954-1990, ed. Clayborne Carson et al. (London: Penguin, 1991), 226.

8 Lawrence R. Samuel, The American Dream. A Cultural History (Syracuse: Syracuse University Press, 2012), 3-4.

9 Samuel, 4-5. 
go unchallenged. As a singular fictional character claiming to represent his disenfranchised hood as well as his black diaspora while still being elected president, Mays Gilliam echoes the American dream of social mobility including its problematic implication that material success depends upon personal efforts alone.

At this point, Donald E. Pease's criticism of the ideology behind the American dream must be remembered, because during the Cold War, this doctrine of American exceptionalism ${ }^{10}$ served to perpetuate the illusion that devoted hard work united American citizens in their projects of national and self-improvement while suppressing discussions about race and class along with the implications of such distinctions in terms of political representation. ${ }^{11}$ In the $21^{\text {st }}$ century, the American dream continues to hold tremendous ideological sway among a multicultural population that invokes exceptional equal opportunities for self-determination as a means to climb the social ladder despite criticism of the condition of the disenfranchised in the U.S. ${ }^{12}$ Since Head of State focusses more on Mays Gilliam's success story than on his origins from a point on, the film risks catering to this dominant U.S. ideology that glosses over issues of social inequality. Therefore, my analysis constantly asks to which extent his character still reminds of the hood's everyday struggles for survival. I particularly want to undertake a critical reading of selected scenes from this film that interweave American exceptionalist myths with cultural patterns fashioning Gilliam's redemptive blackness. Informed by Pierre Bourdieu's theory of habitus, my focus is thereby on how, for example, Mays Gilliam's unlikely electoral success affirms the myth of the American dream while being paradoxically enabled by his familiarity with the disenfranchised in the first place.

\section{The Urban Hood Signifying Oppression and Style}

Tamari Kitossa's discussion of youth gangs from urban ghettos provides

10 Pease traces this term to the Lovestoneite fraction of the Communist International as the belief that the U.S. are unique in the international arena (Donald E. Pease, "Exceptionalism," in Keywords for American Cultural Studies, eds. Bruce Burgett and Glenn Hendler (New York: New York University Press, 2007), 108). Formed around Jay Lovestone, Joseph Stalin expelled this group from the Communist International in 1929 because they suggested the U.S. were exceptional for avoiding socio-economic collapse unlike European nations (Pease 108).

11 Donald E. Pease, "Exceptionalism," in Keywords for American Cultural Studies, eds. Bruce Burgett and Glenn Hendler (New York: New York University Press, 2007), 110.

12 Samuel, 2-3. 
an understanding of hood origins as enabling subjects to learn codes of performing their social difference from the racial and economic mainstream of their societies ${ }^{13}$ and in the following, I will demonstrate how Mays Gilliam's experiences of belonging to this marginalized class in the U.S. are later linked to his expressions of American exceptionalism as a presidential candidate. Head of State thus represents its protagonist in the established tradition of U.S. presidential fictions that constantly seek to determine the ideal characteristics that an American head of state must demonstrate within his own lived reality to act as a national role model. ${ }^{14}$ Yet, the film can be said to stand out because it acknowledges the influence of the hood to inspire a presidential candidate to pursue his American dream although Chris Richardson and Hans A. Skott-Myhre map this space as a transcultural site characterized by marginalization, poverty, and stigmatization. ${ }^{15}$ Additionally, it will be shown how contradictions within American society are sublimated by expressions of national unity and pride when fashioning Mays Gilliam into a point of identification in "the ongoing 'fiction' that is America", to use Smith's phrasing, ${ }^{16}$ when seen through the lens of American exceptionalism.

So, Mays Gilliam's blackness as implying a rootedness in the stereotypical hood and its particular culture which is exhibited in everyday situations must be constantly redefined against existing mainstream paradigms. ${ }^{17}$ In this context, Bourdieu's notion of habitus as a "system of durable and transposable dispositions" informing an individual's "principles which generate and organize practices and representations" 18 can be taken to analyze the ways in which Mays Gilliam performs his blackness in an ambiguous relationship to the dominant American exceptionalist discourse defining and limiting how citizens imagine their country and their destiny as part of it

13 Tamari Kitossa, "Habitus and Rethinking the Discourse of Youth Gangs, Crime, Violence, and Ghetto Communities," in Habitus of the Hood, eds. Chris Richardson and Hans A. Skott-Myhre (Bristol and Chicago: Intellect, 2012), 126.

14 Smith, 7.

15 Chris Richardson and Hans A. Skott-Myhre, introduction to Habitus of the Hood, eds. Chris Richardson and Hans A. Skott-Myhre (Bristol and Chicago: Intellect, 2012), 10.

16 Smith, 9.

17 George Yúdice, "Culture," in Keywords for American Cultural Studies, eds. Bruce Burgett and Glenn Hendler (New York: New York University Press, 2007), 71.

18 Pierre Bourdieu, Outline for a Theory of Practice, trans. R. Nice (Cambridge: Cambridge University Press, 2007), quoted in Richardson and Skott-Myhre, 9. 
when understood as an ideology, to follow Pease. ${ }^{19}$ It will be seen that Mays Gilliam's particular aptness to represent the U.S. is imagined as the result of his embodiment of the stereotypical urban hood.

Consequently, Mays Gilliam's belonging to the multicultural and economically deprived community he calls his hood serves both as a mark of distinction within his political party and as evidence of his American-ness. This depiction of his domestic hood serves to construct Mays Gilliam's legitimacy as a cultural outsider to "authentically" advocate for justice for fellow "others" and thereby perform multiculturalist solidarity ${ }^{20}$ as opposed to the mainstream characterized by Leo Marx as rural, landowning, politically conforming, white Americans ${ }^{21}$ whose hegemonic dominance is attested by the presumed necessity of his early campaign speeches to flatter them. From the start, the reproduction of the rural gaze upon his urban hood as the crime-ridden "part of D.C. you're probably not familiar with" 22 prefigures Mays Gilliam's demand for the recognition of his black culture as American which unsettles the discursive tactics of white supremacy that developed after the Civil Rights Movements, including, for example, to blame minorities for their subjugation. ${ }^{23}$ This strategy especially inheres in the rhetoric of equating an individual's failure to achieve the national ideal of upward social mobility with personal vice that Jennifer L. Hochschild criticizes $^{24}$ all the more because it sustains public faith in the American dream despite obvious evidence of its elusiveness ${ }^{25}$.

First of all, it must be understood that depictions of Mays Gilliam's socially critical perspective of the establishment as the result of his experiences of oppression must remain contained within the ideological confines of American exceptionalism in order to legitimate his later success as a president. His work as Alderman of the $9^{\text {th }}$ district of Washington, D.C. obliges Mays Gilliam to mediate in his domestic multicultural and destitute hood,

19 Pease, 109.

20 Yúdice, 73.

21 Leo Marx, "Pastoralism in America," in Ideology and Classic American Literature, eds. Sacvan Bercovitch and Myra Jehlen (Cambridge: Cambridge University Press, 1986), 46-47.

22 Head of State.

23 Yúdice, 73.

24 Jennifer L. Hochschild, Facing Up to the American Dream: Race, Class, and the Soul of the Nation (Princeton: Princeton University Press, 1995), 31.

25 This discursive structure is elastic. Evidence can be found in the film itself when Mays Gilliam's response to criticism of his audience-approved use of the word "shit" that does not follow the rhetorical norms established by past white candidates, equates obedience to the latter with moral corruption (Head of State). 
whose inhabitants must be made to accept limitations imposed by "them" from without who possess the power to close down a necessary bus line or to regulate the "correct" use of food stamps. In the film Head of State, Mays Gilliam's specifically black perspective originates from such experiences of political powerlessness, fueling his redemption of civil heroic virtue that represents the mythological U.S. and compensates for the unequal distribution of power in the contemporary society while he is also distinguished from fellow negatively connoted hood inhabitants. ${ }^{26}$

Given this setting, the point can be made that by imagining national unity to emerge, the film demonstrates a basic ideological conformity in its portrayal of a fictional black president who voices a contained critique of the American status quo. Significantly, Mays Gilliam initially defends the hood despite a recent case of bicycle robbery, following an official's dismissal of the space as a "rat-trap" and he delivers his rant in front of the campaign poster of presidential candidate Brian Lewis featuring the latter's slogan "God Bless America and No Place Else". ${ }^{27}$ In this sense, a consciousness of the clichéd hood's difference on the grounds of its key aspects that Richardson and Skott-Myhre label "negative and threatening to mainstream values - to mainstream habitus" 28 here surfaces in Mays Gilliam's demand for incorporating the clichéd hood that shaped his black perspective, into the unrevised imaginary landscape of the U.S.

At first, Mays Gilliam's early statement that in the hood "they don't call the mayor, they call me" 29 functions to distance this space and his role as its ward from more conventional systems of government while reviving 1960s Black Power notions of separate self-governance for minority communities. ${ }^{30}$ In this sense, the depicted prototypical hood's system of self-regulation alludes to the real wide-spread perception that public neglect continues to affect disenfranchised African American communities, ${ }^{31}$ which are additionally suffering from political condemnation and media misrepresentation. ${ }^{32}$ It can be said, however, that during the course of the

28 Richardson and Skott-Myhre, 11.

29 Head of State.

30 Tommie Shelby, We Who Are Dark: The Philosophical Foundations of Black Solidarity (Cambridge: Belknap Press of Harvard University Press, 2005), 109.

31 Shelby, 103.

32 Kitossa, 123. 
film, the stylization of Mays Gilliam as an authority on the hood serves to integrate the pattern of a black socially critical discourse into the American mythological image of a government created for the people and led by a president who best embodies those views that a nation holds of itself. ${ }^{33}$

Indeed, the American exceptionalist framing of Mays Gilliam's success story is evident when he is offered his unnamed political party's presidential nomination because he is "a man of the people" who "care[s] about the little people" in front of a picture of the Lincoln Memorial at Gettysburg, Virginia surrounded by the quotation from the American Constitution that "We hold these truths to be self-evident, that all men are created equal". ${ }^{34}$ Following Paul Gilroy's arguments from The Black Atlantic, one could assume that pity and guilt among the political establishment which stem from the hegemonic suppression of the memory of slavery in the U.S., ${ }^{35} \mathrm{com}$ pel the white Founding Fathers' descendant, Bill Arnot to call an African American, Mays Gilliam, to his civil duty of redeeming the democratic spirit of the nation with reference to the historical moment that saw the black slaves freed. However, Mays Gilliam's prompt answer to the question of his American-ness, the ensuing military parade music, the earlier symbolically imbued presences of the book on "Prince George's" Washington D.C. on his office desk and the "Mayflower" truck in front of which he parks his car, serve to conflate the American dream of equality with a belief in the virtue of the American political and economic system affording a place to this common man.

Mays Gilliam's potential to represent American exceptionalist notions for racial minorities is attested by the hip hop music that functions as a leitmotif in this narrative fashioning the origins of a presidential candidate's personal moral integrity. Thus, his success is anticipated while his individualism is highlighted at every occasion that the same verse from the song "Bonnie and Clyde" (2003) by Jay-Z featuring Beyoncé is replayed, which echoes the American dream of social mobility, of being "young, free, cruising down the Westside highway, doing what we like to do our way". ${ }^{36}$ Elements of the realized American dream that is essential to the existence of the American exceptionalist myth of equal opportunity, are marked by indicating that the winners have emigrated away from the hood and into the

\footnotetext{
33 Smith, 7-9.

34 Head of State.

35 Gilroy, 77.

36 Head of State.
} 
middle class, according to Hochschild.$^{37}$ These are here translated through the medium of music with the appeal to communal liberation through an individual token of success. However, George Yúdice originally classified identity renegotiation as a strategy of minority cultural resistance which, in the light of Mays Gilliam's later rise to presidency, this presidential narrative risks commodifying to legitimate the establishment he integrates into. ${ }^{38}$

Yet, judging by the uncondescending first reactions of members of his campaign team that fashion Mays Gilliam into an advocate for all oppressed people of the U.S. on the basis of his black hood origins, ${ }^{39}$ his speech on "what the people need" 40 epitomizes the film's efforts to strengthen faith in the American political system. At this point, we can imagine how a presidential candidate may earn the trust of his country's public precisely by refusing to deploy any rhetoric rooted in U.S. history. Instead, Mays Gilliam's agenda is exclusively informed by his personal experiences of the hood that paradoxically came to exist through the neglect of establishment politics. Like his hood origins, Head of State invokes his identity as a black man through cultural references that establish him as a figure of identification for a diasporic community united by legacies of oppression. The definitive characteristic of black diaspora music that Gilroy identifies, the narrative structure of call and response, here also frames the moments in which the film's black protagonist enters into potentially liberating relationships with members of the communities he addresses. ${ }^{41}$ When Mays Gilliam speaks to diverse audiences, they reactivate the memory of their grievances at the hands of a still-corrupt establishment. While he performs this black Atlantic rhetorical tradition of blending his voice within that of the crowd $\mathrm{d}^{42}$ following his introductory rejection of the speech "they had [...] written for me", ${ }^{43}$ his closing proclamation of his presidential race and his campaign's commercialization of his message "That Ain't Right" relativize the function of the speech as inherently subversive. Although it adheres to the black diaspora's cultural codes, the speech contributes to upholding the egalitar-

37 Hochschild, 35.

38 Yúdice, 74.

39 Barbara Cruikshank, "The Will to Empower: Technologies of Citizenship and the War on Poverty," Socialist Review 23, no. 4 (1994), quoted in Yúdice, 73.

40 Head of State.

41 Gilroy, 78-79.

42 Gilroy, 200.

43 Head of State. 
ian myth of a so-called "man of the people" 44 having the chance to achieve success by virtue of the American political system he is governed by.

\section{The American Dream Refashioned for the Black Diaspora}

I will show that it is through a performed heightened sense of own corporeality developed out of the cruelty of the institution of plantation slavery in the West ${ }^{45}$ that Mays Gilliam's belonging to the black diaspora is expressed. Considering this collective's historical displacement through slavery, already his corporeal appearance as a black man in a position of leadership presents an opportunity for empowering identification and possibly cultural resistance for fellow black populations. The ways in which he performs his black male corporeality may thus be studied in terms of how they reference lived realities circulating within this black community across cultures that he claims to represent. As a black man from the hood, Mays Gilliam must voice critiques of racist violence and economic oppression through neoliberal capitalism in order to adequately "represent my whole race". ${ }^{46}$ Like any future president, he must also, however, serve as a site of projection for national memories when he performs his corporeality. ${ }^{47} \mathrm{He}$ faces this challenge when he claims belonging to a black diaspora transgressing national borders on the grounds of racialized identity performances and in defiance of political marginalization. These principles constitute the priorities of minority politics in the U.S. according to Roderick A. Ferguson, ${ }^{48}$ but do so precisely because of their rhetoric which rejects the complacency of the white middle-class mainstream. Yet, while running for President of the U.S., Mays Gilliam must mediate signs of his personal blackness when these clash with timeless expectations tied to this office. As understood by Novak, popular presidents are successful at fashioning themselves into relatable icons for the American people that help them contextualize their present marked by problems and disseminate the illusion of an improved national identity within a given cultural dynamic. ${ }^{49}$

44 Head of State.

45 Gilroy, 75.

46 Head of State.

47 Smith, 7.

48 Roderick A. Ferguson, "Race," in Keywords for American Cultural Studies, eds. Bruce Burgett and Glenn Hendler (New York: New York University Press, 2007), 192.

49 Novak, 9. 
As is the case with respect to his black hood origins, Mays Gilliam's self-fashioning as an embodiment of his racialized community's struggles for positive representation rests on constant reaffirmations of an affluent white perspective within American politics and culture. In this sense, the difference between his campaign headquarters before and after his change of style following the rise of his slogan "That Ain't Right" can only be described as innovative and unashamedly black when he chooses tokens of "my people" 50 to inspire him rather than George Washington, whose portrait he removes. By this act of choosing, a future president shapes his cultural era and immortalizes himself in the national imaginary, ${ }^{51}$ here, however, by reactivating the viewer's consciousness of these all-black individuals' previous invisibility in mainstream American political representations of the minority.

Once again, it is through habitus as defined by Bourdieu that the community's past of exclusion perpetuates itself into the present through symbols, ${ }^{52}$ and stereotypes of blackness, like stereotypes of hood origins, traditionally signify a subordinate position in discourses on power in the post-slavery West. ${ }^{53}$ Accordingly, the filmic construction of Mays Gilliam's identity as a black man acts as a pars pro toto for that of the entire diaspora as it must begin with an evocation of the external forces in society that, as imagined by Michel Foucault, fuel distinct manifestations of the institutionally calibrated identities of citizens as a response..$^{54}$

The film Head of State is constantly obliged to match the depiction of racial inequality with expectations of presidential moral guidance, ${ }^{55}$ in the following example by opposing the U.S.' objectionable past with the hope of future improvement through the dominance of an inherently virtuous group though redefined. It is especially on the basis of his identification with hitherto underprivileged groups that Alderman Mays Gilliam's story commends returning to simplistic imaginations of the American nationstate. This point can be made with reference to the televised debate in which Mays Gilliam's rhetorical devices include the sexualized metaphor 
of the U.S. he envisions as a "big-titty woman"56 and the enumeration of black amateur performers distinguished by virtue of their talent rather than expertise. The motif of black diaspora corporeal forms of expression as a counterpoint to white rationale ${ }^{57}$ is further worked into the fabric of the American myth of the everyman's democracy and underlined by his rival Brian Lewis' technical metaphor of the U.S. as a "fine performance car" 58 requiring a driver distinguished by know-how.

I argue that the stereotyping which complicates Mays Gilliam's black diaspora belonging, sets in at his rescue of his white neighbor Miss Pearl from a fire when he unintentionally acts complicit with the establishment's neglect of his hood that, in turn, fundamentally shapes his black perspective. ${ }^{59}$ What surfaces here is the motif of a black man risking his life while supporting his white oppressors in defending their status quo that includes the republican trope of the virtuous common man under American democracy. Heike Paul described this cultural pattern in her analysis of the horror film The Shining (1980; dir. Stanley Kubrick), where it is not an inhabitant of the multicultural hood but Native American spirits whose actions, when seen as acts of protest, simultaneously bring to light and sublimate undisclosed struggles over land ownership and property rights. ${ }^{60}$ The importance of the territorial gaze upon the hood that is acknowledged by the film furthermore anticipates the later Americanizing celebration of Mays Gilliam's corporeal performance of selfless heroism through Bill Arnot. Mays Gilliam's own success and performances of American values prevent any subversive, anti-capitalist consciousness to arise among the hood's inhabitants. As a result, the attention of his white viewers is primarily drawn to the necessity to incorporate racial minority perspectives into the American political and economic systems rather than to fundamentally revise them.

56 Head of State.

57 Gilroy, 79.

58 Head of State.

59 Indeed, Mays Gilliam's position in discourses on the hood's self-representation as "black" is clearly fixed. Not coincidentally does the first scene of the film see him pacifying an inhabitant's outrage at a Chinese restaurant selling "fried rice" (Head of State). The pun on the word "fried" alludes to the "conks" worn by many African American men in the early $20^{\text {th }}$ century who attempted to look "white" by chemically straightening or "frying" their natural hair (Malcolm X and Alex Haley, The Autobiography of Malcolm X (London: Penguin, 2001), 138).

60 Heike Paul, "Das Unheimliche und die Präsenz: Fremdheit in der amerikanischen Gegenwartsliteratur und - kultur," in Phänomene der Fremdheit: Fremdheit als Phänomen, eds. Simone Broders, Susanne Gruß and Stefanie Waldow (Würzburg: Königshausen \& Neumann, 2012), 104. 
In the film Head of State, manifestations of belonging to a black diaspora community ultimately situate Mays Gilliam within the American exceptionalist discourse described by Pease as claiming a unique status of authority for the American government with regard to fellow nations ${ }^{61}$ In this sense, the conclusion of his debate with Brian Lewis appears to contradict his opponent's slogan "God Bless America and No Place Else", but the examples he mentions in his demand to include countries typically considered inferior in an American exceptionalist worldview, still reflect notions which flatter the U.S.' revolutionary foundations. Especially Mays Gilliam's stress that "stabbing Jamaica" and Haiti, ${ }^{62}$ whose enslaved black populations overthrew European colonial governments, should also be blessed, at once celebrates the legacy of resistance in the black diaspora but equally American exceptionalism, as it dichotomizes the world of nations. However, he here claims superiority for "others" too, if they also revolted against domination by foreign monarchies and feudal élites. ${ }^{63}$

Another performance of black diaspora communality that signifies complicity with American exceptionalism is the dance initiated by Mays Gilliam at his presidential campaign's fundraising gala. His intention of thus "get[ting] to know" his love interest Lisa Clark and the slap he gives a black "brother" ${ }^{64}$ a security guard, making the latter instinctively break into hip hop dance, first point toward an understanding of corporeal arts as integral to the formation of a black diaspora community united through time by shared traditions. Nevertheless, it must not be forgotten that he later invites white attendees to dance with him to the song "Hot in Here" (2002) by Nelly and thereby redefines his identity as separate from the white élite while still endorsing the idealized image of the American melting pot. $\mathrm{He}$ thus performs his blackness through cultural codes of expression that he seems to have internalized. The problem is, however, that the consumption of such identity performances by whites for their entertainment risks depicting them as essentially pluralistic and progressive with respect to "others" of diverse ethnic backgrounds despite their ongoing exploitative objectification of the latter. ${ }^{65}$ The wealthy white sponsors' instinctive attrac- 
tion to Mays Gilliam may actually be rooted in their fetishistic appetite for sexual exuberance which they associate with Africa in the footsteps of the 1920s "Negrophile" avant-garde in Europe that Petrine Archer indicts for stereotyping and commodifying the cultures of the black diaspora. ${ }^{66}$

When it comes to subverting the socio-political critique inherent in Mays Gilliam's imagined rise to the presidency, a useful tool to make it fit within the elastic confines of American exceptionalism is the depiction of his story as a journey toward the full embodiment of traditional patriarchic gender stereotypes. The reason for this can be found in the need for his character to develop a presidential body politic which must both command authority in the view of his community, ${ }^{67}$ here meaning especially that of "my whole race" ${ }^{68}$ while also abiding by commonplace conceptions of liberal democracy in the U.S. which further define citizens' terms of expression regarding sexual morality. The latter had already been prescribed by early $20^{\text {th }}$ century racializing sociologists in the U.S. before entering into the rhetoric of future black empowerment movements. ${ }^{69}$ An example of Mays Gilliam advertising for the Western Christian ideal of the nuclear family structured according to patriarchal norms is his demand at a children's daycare center that "everybody [...] take care of their own damn kids".$^{70}$ He thereby devalues their struggling working mothers and follows traditional white American paradigms as well as black decolonial leaders by idolizing the reproduction of traditional gender roles that are fantasized as being redemptive for their communities ${ }^{71}$ and stylized here as the foundations of Mays Gilliam's moral integrity in his upbringing.

I want to stress that the black diaspora pop-cultural pattern of the love story identified by Gilroy ${ }^{72}$ once again links Mays Gilliam's final successes to the realization of the American dream requirements of liberal individualism and Christian virtue, as he also fully embraces patriarchal gender roles typifying tradition. Significantly, the happy end of the film closes on the picture of the romantic heterosexual couple consisting of Mays Gilliam -

(New York: New York University Press, 2007), 107.

66 Petrine Archer, "Negrophilia, Diaspora, and Moments of Crisis," in Afro Modern: Journeys through the Black Atlantic, eds. Tanya Barson and Peter Gorschlüter (Liverpool: Tate, 2010), 30-32.

67 Smith, 7.

68 Head of State.

69 Ferguson, 194-195.

70 Head of State.

71 Ferguson, 194.

72 Gilroy, 201. 
rendered omnipotent by his election, and Lisa Clark acting as a symbolic reunification of the black community because of his turn to "authentic" self-representation, for example, by choosing his zoot suit-wearing broth$\mathrm{er}^{73}$ to be his running mate. They further adhere to traditional black diaspora concepts of masculinity as a) focused on "redemptive" relationships with black women rather than recurring to the white prostitute their party had provided for them, and as b) an expression of counter-violence ${ }^{74}$ against exploitative institutions, which Mitch Gilliam threatens to punish harshly. He therefore receives the admiration of Mays Gilliam's African American campaign coordinator, Debra Lassiter. It must be remembered that such patterns of performing an "authentic" ethnic self always already depend upon constructing associations with symbols of the respective ethnic community's origins, ${ }^{75}$ a mechanism exemplified by this representation of the hood ward Mays Gilliam with his preferred style of hip hop fashion and music.

\section{American Exceptionalism through the Lens of Presidential Blackness}

As illustrated by my readings of different scenes from a film imaging an African American president with a particular focus on the themes of hood origins and black diaspora belonging, the use of patterns distinguishing Mays Gilliam from the affluent white American élite must be seen as a key element constituting the overall significance of his election as an "exceptional" success. Accordingly, my interpretation of these scenes pointed out the processes by which the depicted American president's story can be generalized to express certain cultural imaginaries which are shared throughout the U.S. and beyond.

To further support my conclusion, I would like to allude to Mays Gilliam's suggestion to subtitling music videos in the course of his debate with Brian Lewis as well as to the preceding invocations of fearful respect

73 Mitch Gilliam's appearance aesthetically refers back to the roots of black diaspora cultural resistance especially because he sports this fashion trend from the 1920s New Negro movement that re-appropriated "primitive" cubic shapes from white Surrealist art (Robert Farris Thompson, "Afro-Modernism," in Artforum (September 1991), quoted in Tanya Barson, "Introduction: Modernism and the Black Atlantic," in Afro Modern: Journeys through the Black Atlantic, eds. Tanya Barson and Peter Gorschlüter (Liverpool: Tate, 2010), 10).

74 Gilroy, 63.

$75 \mathrm{Yu}, 107$. 
toward the latter's mother that he employs in his determination to challenge his opponent. As both instances show the same intention - to portray Mays Gilliam as an unconventional candidate and thus as an especially qualified leader of the American people - a single glance at the way his blackness is here depicted, reveals its importance for comprehending both the allpervasiveness of the American exceptionalist ideology and two main areas of its focus with respect to the topic of change: hood origins and black diaspora belonging.

The explanation for his recommendation to turn to music as a means for legislators to address broad masses of people is based on his knowledge of the conditions of urban hoods. It is a critique based on registering factual evidence in the tradition of the American Declaration of Independence (1776) and likewise aimed at calling for future administrations to not impose themselves upon, but await election by citizens based on their commonsense. ${ }^{76}$ This is, however, to be achieved in the hood by ideologically imbuing its preferred pop-cultural products. Such an act of tying an artist's success to their position of political conformity would reproduce the problematic equation of poverty with vice that underwrites the myth of the American dream. ${ }^{77}$ This proposition would also signify that disobedience to establishment rules legitimates discriminating against the political perspectives of those who remain underprivileged, ${ }^{78}$ condemning them as "losers" in the American economic system, and it would finally risk motivating them to abandon their countercultural communities. ${ }^{79}$

The offences to Brian Lewis' mother that Mays Gilliam delivers below his opponent's office window meanwhile refer to the motif of violent motherly chastisement discussed by Gilroy in the works of black diaspora writers such as Richard Wright or James Baldwin. ${ }^{80}$ This challenge to Brian Lewis' secretive and boastful aristocratic style of governance merges the experiences of members of unequally privileged groups. Both are called upon to surrender to corporeal pain that Gilroy sees perpetuated through African American family structures and required for the racially hierarchizing public order to persist in climates of segregation and oppression such

76 Smith, 8 .

77 Hochschild, 31.

78 Kitossa, 129.

79 Hochschild, 31-34.

80 Gilroy, 174-175. 
as in the American South. ${ }^{81}$ By virtue of his origins, Mays Gilliam's call to competition also fashions him as the redeemer of the idealized American system of free election, which necessitates the open debate of competing presidential candidates - the role that legitimates his efforts to realize his dream to be the Head of State. ${ }^{82}$

However, I want to mention that any cultural narrative imagining an American president's all-over "otherness" compared to affluent white predecessors can cause a moment of resistance against the American exceptionalist paradigm of success as the achieved triumph of "virtue" over "vice", as defined according to the standards of a dichotomized global order ${ }^{83}$ As the rhetoric of icons of political dissent in texts such as Martin Luther King Jr.'s speech "I Have a Dream" (1963) reveals, the American national aim of overcoming the crises of the present in order to eventually accomplish perfection is also shared by groups commonly removed from discourse in the mythological U.S. Indeed, drawing a parallel with the rhetoric of this Civil Rights Movement icon, a black man's rise to public influence in this kind of political climate marked by oppression and exclusion and here its cinematic depiction can be imagined to entail a redemption of "the soul of America" that must be protected from any ravages of reality. ${ }^{84}$ Given enduring cultural politics of exclusion, the possibility for a minority president to market change as progress for the American people can only be imagined to lie in their performances of an "other" habitus shaped by familiar counterperspectives but assimilated to the norms of the mainstream ideology by affirming American exceptionalism and thus their own American-ness.

81 Gilroy, 175.

82 Head of State.

83 Pease, 111.

84 Martin Luther King Jr. (1967), "A Time to Break Silence," in The Eyes on the Prize. Civil Rights Reader: Documents, Speeches, and Firsthand Accounts from the Black Freedom Struggle, 1954-1990, ed. Clayborne Carson et al. (London: Penguin, 1991), 390. 


\section{Bibliography}

Archer, Petrine. "Negrophilia, Diaspora, and Moments of Crisis," In Afro Modern: Journeys through the Black Atlantic, edited by Tanya Barson and Peter Gorschlüter, 26-39. Liverpool: Tate, 2010.

Barson, Tanya. "Introduction: Modernism and the Black Atlantic," In Afro Modern: Journeys through the Black Atlantic, edited by Tanya Barson and Peter Gorschlüter, 8-25. Liverpool: Tate, 2010.

Bourdieu, Pierre. Outline for a Theory of Practice. Translated by R. Nice. Cambridge: Cambridge University Press, 2007.

Cruikshank, Barbara. "The Will to Empower: Technologies of Citizenship and the War on Poverty." Socialist Review 23, no. 4 (1994): 29-55.

Farris Thompson, Robert. "Afro-Modernism.” Artforum (September 1991): 91-94.

Ferguson, Roderick A. "Race," In Keywords for American Cultural Studies, edited by Bruce Burgett and Glenn Hendler, 191-196. New York: New York University Press, 2007.

Foucault, Michel. Discipline and Punish. London: Penguin, 1979.

Gilroy, Paul. The Black Atlantic: Modernity and Double Consciousness. Cambridge: Harvard University Press, 1993.

Hochschild, Jennifer L. Facing Up to the American Dream: Race, Class, and the Soul of the Nation. Princeton: Princeton University Press, 1995.

King, Martin Luther Jr. (1965). "Our God is Marching On," In The Eyes on the Prize. Civil Rights Reader: Documents, Speeches, and Firsthand Accounts from the Black Freedom Struggle, 1954-1990, edited by Clayborne Carson et al., 224-227. London: Penguin, 1991.

King, Martin Luther Jr. (1967). “A Time to Break Silence,” In The Eyes on the Prize. Civil Rights Reader: Documents, Speeches, and Firsthand Accounts from the Black Freedom Struggle, 1954-1990, edited by Clayborne Carson et al., 387-393. London: Penguin, 1991.

Kitossa, Tamari. "Habitus and Rethinking the Discourse of Youth Gangs, Crime, Violence, and Ghetto Communities," In Habitus of the Hood, edited by Chris Richardson and Hans A. Skott-Myhre, 123-142. Bristol and Chicago: Intellect, 2012.

Marx, Leo. "Pastoralism in America," In Ideology and Classic American Literature, edited by Sacvan Bercovitch and Myra Jehlen, 36-69. Cambridge: Cambridge University Press, 1986.

Novak, Michael. Choosing Our King. Powerful Symbols in Presidential Politics. New York: Macmillan, 1974.

Paul, Heike. "Das Unheimliche und die Präsenz: Fremdheit in der amerikanischen Gegenwartsliteratur und - kultur," In Phänomene der Fremdheit: Fremdheit als Phänomen, edited by Simone Broders, Susanne Gruß, and Stefanie Waldow, 95-116. Würzburg: Königshausen \& Neumann, 2012.

Pease, Donald E. "Exceptionalism," In Keywords for American Cultural Studies, edited by Bruce Burgett and Glenn Hendler, 108-112. New York: New York University Press, 2007.

Richardson, Chris and Hans A. Skott-Myhre. Introduction to Habitus of the Hood, 9-26. Edited by Chris Richardson and Hans A. Skott-Myhre. Bristol and Chicago: Intellect, 2012.

Rock, Chris, dir. Head of State. Universal City: DreamWorks, 2003. DVD.

Samuel, Lawrence R. The American Dream. A Cultural History. Syracuse: Syracuse University Press, 2012.

Shelby, Tommie. We Who Are Dark. The Philosophical Foundations of Black Solidarity. Cambridge: Belknap Press of Harvard University Press, 2005. 
Smith, Jeff. The Presidents We Imagine: Two Centuries of White House Fictions on the Page, on the Stage, Onscreen, and Online. Madison: Wisconsin University Press, 2009. X, Malcolm and Alex Haley. The Autobiography of Malcolm X. London: Penguin, 2001.

Yu, Henry. "Ethnicity," In Keywords for American Cultural Studies, edited by Bruce Burgett and Glenn Hendler, 103-108. New York: New York University Press, 2007.

Yúdice, George. "Culture," In Keywords for American Cultural Studies, edited by Bruce Burgett and Glenn Hendler, 71-76. New York: New York University Press, 2007. 
